\title{
A bio-economic appraisal of pair trawl fisheries off southeastern Brazil ${ }^{1}$
}

\section{(Uma análise bio-econômica da pesca de parelhas no sudeste do Brasil)}

\author{
Luiz Arnaud Britto de Castro *; Miguel Petrere Jr. ** \& Antônio Evaldo Comune*** \\ * Centro de Pesquisa Pesqueira Marinha do Instituto de Pesca \\ (Av. Bartolomeu de Gusmão, 192, 11030-906, Santos, São Paulo, Brasil) \\ ** Universidade Estadual Paulista, UNESP, Departamento de Ecologia \\ (Caixa Postal 199, 13506-900, Rio Claro, Brasil) \\ *** Faculdade de Economia , Administração e Contabilidade da Universidade de São Paulo \\ Departamento de Economia \\ (Av. Prof. Luciano Gualberto, 908, 05508-900, São Paulo, Brasil)
}

- Abstract: A study of the pair trawl fisheries was made in an attempt to introduce bioeconomic models into fishery management in southern and southeastern Brazil. The biological parameters of demersal fishes found in the literature were used to mount the bioeconomic model. Since there are no historical data on the economics of the fishery industry, the present market values of fish and of the diverse items that compose the costs of the catch have been used. The results show that the fleet was oversized in the period 1976-1981. The number of boats was reduced from 28 pairs to only 11 in 1996, but was still considered too big. The size of the fleet is reflected in the economic results of the analysis which shows negative returns. However, the fact that some of the fixed costs are not actually spent by the owners of the boats, as many of them have no insurance and most of the boats are already completely paid off and do not accrue costs on the capital invested must all be taken into account. On the other hand, the income figures used in this analysis did not take into account the value of the by-catch landed.

- Resumo: Numa primeira tentativa de introduzir modelos bio-econômicos no gerenciamento pesqueiro no sudeste e sul do Brasil realizou-se um estudo da pesca de parelhas. Para isso construiu-se um modelo utilizando os parâmetros biológicos disponíveis na literatura. Como não há registros históricos de dados econômicos da pesca, foram utilizados os valores atuais do pescado e dos diversos insumos utilizados nessa atividade. Os resultados indicam que a frota estava superdimensionada no período de 1976-1981. De fato, daquela época até 1996, essa frota reduziu-se de 28 parelhas para apenas 11 , um número ainda excessivo. O superdimensionamento da frota reflete-se nos resultados econômicos da análise, na forma de retornos financeiros negativos. Entretanto, deve-se levar em conta que alguns dos custos fixos não representam efetivo desembolso por parte dos armadores, uma vez que muitos deles não têm seus barcos segurados, ao mesmo tempo que a maioria dos barcos já estão totalmente amortizados e não apresentam mais custos sobre o capital. Por outro lado, as rendas consideradas não incluem o valor da fauna acompanhante desembarcada.

- Descriptors: Bio-economic models; Pair trawling; Demersal fishes; Micropogonias furnieri; Macrodon ancylodon, Cynoscion jamaicensis; Brazil.

- Descritores: Modelos bio-econômicos; Arrasto de portas, Peixes demersais; Micropogonias furnieri; Macrodon ancylodon; Cynoscion jamaicensis; Brasil. 


\section{Introduction}

Demersal fishes have been caught off southsoutheastern Brazil since the decade of the fifties, when the first pair trawlers, belonging to the "Taiyo Fisheries Company", began to operate in this region. In the late sixties and early seventies, due to the creation of SUDEPE (Superintendency for Fishery Development) and the sanction by the Federal Government of Decree-Law no. 221, on February 28, 1967 (BRASIL-SUDEPE, 1969), that allowed fiscal subsidies for national fishery enterprises, there was a great increase in the fishing activity in this area. Although the larger part of the investments and, consequently, the greater increase in the fleet was directed to the catching and processing of shrimps, for which excellent export markets existed, the capture of fish was also greatly incentivated.

Since 1972-1973, when the shrimp catch started to decline, possibly due to overfishing by an oversized fleet, many boats transferred their activities to the pair trawling of demersal fishes the populations of which now reflect the consequences of the heavy fishing to which they have been subject for more than a decade. This is evidenced by the decrease observed in the mean CPUE of Micropogonias furnieri and Macrodon ancylodon for the period 1977-1986 as compared with that of 1967-1976 (Valentini et al., 1991). This conclusion is reinforced by the results of Castro \& Castro (1995) who analyzed the variations in the mean length of Macrodon ancylodon landed in Santos (SP - Brazil) from 1976 to 1990.

The pair trawler fleet that operates off southsoutheastern Brazil was composed, in the late seventies and early eighties, of 56 boats ( 28 pairs) of which only 22 (11 pairs) were still in operation in 1996. These are boats with a mean length of $20.17 \mathrm{~m}$, powered by $260 \mathrm{HP}$ engines, using trawling nets with meshes of $90 \mathrm{~mm}$ between opposite knots at the wings and $50 \mathrm{~mm}$ at the codend, in three-hour hauls.

The species of greater commercial interest caught by this fleet are "Corvina" (Micropogonias furnieri), "Pescada-foguete" (Macrodon ancylodon), "Goête" (Cynoscion jamaicensis) and, more recently, "Peixe-porco" (Balistes capriscus).

We are now in a situation in which the catch is insufficient to meet the demand of the consumer markets, thus generating high prices; but nevertheless not producing sufficient income to cover operational costs or permit adequate remuneration for boat owners (capital) or crew (labour).

As many authors, such as Gordon (1954), Hardin (1968), Randall (1987) and McKelvey (1989), attribute the inefficiency of the management process to a lack of consideration regarding the economic characteristics of fish (common property), one would need a system of fisheries management that took into account not only the state of the exploited stocks but also the costs of their exploitation.

The availability of economic analyses of these fisheries would permit resource managers to identify the most effective measures for the attainment of the desired socio-economic results of the exploitation. At the same time, such analyses would allow fishery managers to ascertain which costs could be reduced or what other steps could be taken to increase profitability.

A model using the equations proposed by Sparre \& Willmann (1993) was developed using Excel worksheets to analyze the pair trawl fisheries off southeastern Brazil and define the fleet size that would give maximum economic yield after achieving a balance. This paper aims to present the results of this first attempt to carry out an economic analysis of the profitability of pair trawler fisheries off southeastern Brazil and the estimates, obtained through simulation, of the Maximum Sustainable Economic Yield for a fleet exploiting only the southeastern stocks of "corvina", "pescada-foguete" and "goête".

\section{Material and methods}

For this study only the populations of "corvina", "pescada-foguete" and "goête" occurring between Cabo Frio $\left(23^{\circ} \mathrm{S}\right)$ and Cabo de Santa Marta $\left(29^{\circ} \mathrm{S}\right)$ were taken into consideration. The "peixeporco" was not included, since no data on the selectivity of the fishing gear for this species were available. A description of these species may be found in Castro (1998). A brief description of the source of the biological parameters of these species used to feed the model follows:

a) corvina - Vazzoler (1971) estimated $\mathrm{L}_{\infty}=$ $632.3 \mathrm{~mm}$ and $\mathrm{K}=0.19$ year $^{-1}$. Pauly's empirical formulas (Pauly, 1980; Pauly \& Martosubroto, 1980) were applied to obtain $M=0.45$ year $^{-1}$ and $\mathrm{t}_{0}=-0.73$ year. Isaac-Nahum \& Vazzoler (1983) found the exponent for the weight/length relationship to be 3.03 and the coefficient 0.000009 g. $\mathrm{mm}^{-3.03}$. Richardson \& Santos (1962) defined the selectivity parameter $\mathrm{L}_{50 \%}$ for this species as $182.0 \mathrm{~mm}$. $\mathrm{L}_{75 \%}(=244.6 \mathrm{~mm})$ was calculated assuming $\mathrm{L}_{50 \%} / \mathrm{L}_{75 \%}$ for $M$. furnieri to be equal to $\mathrm{L}_{50 \%} / \mathrm{L}_{75 \%}$ for Umbrina canosai, obtained by Vooren (1983), since both are sciaenidae with approximately the same body proportions. The catchability coefficient was obtained from the relationship $q=F / f$ (fishing mortality/ fishing effort) with the value of $\mathrm{f}$ taken from the fishery statistics produced by the Instituto de Pesca and the value of F suggested by PDP/SUDEPE (1981), giving $q=0.00005$. 
b) pescada-foguete - Isaac-Nahum (1989) defined $\mathrm{L}_{\infty}$ as $49.69 \mathrm{~cm}$ and $\mathrm{K}=0.388$ year $^{-1}$. Weight/length exponent and coefficient, obtained by Coelho et al. $\left(1995^{*}\right)$ were, respectively, 3.2535 and $0.003117{\mathrm{~g} . \mathrm{cm}^{-3.2535}}^{-} \mathrm{M}=0.77$ year $^{-1}$ and $t_{0}=-0.37$ year were calculated by Pauly's empirical formulas (Pauly, 1980; Pauly \& Martosubroto, 1980). q was obtained by the equation $\mathrm{q}=\mathrm{F} / \mathrm{f}$ with $\mathrm{F}=\mathrm{Z}-\mathrm{M}$, where $\mathrm{Z}=1.41$ (Yamaguti, 1967) resulting in $q=0.00008 . \quad L_{50 \%}$ was calculated from Richardson \& Santos (1962) as $22.40 \mathrm{~cm}$, while $\mathrm{L}_{75 \%}$, calculated in the same way as for corvina, with values from Vooren (1983) for this same species, resulted in $29.60 \mathrm{~cm}$.

c) goête - Santos [1968] using Ricker's (1958) equation $(Z=M+F-M F)$ found $M=0.57$ year $^{-1}$. The values for $L_{\infty}$ and $K$ found by Isaac-Nahum (1989) were used: $35.7 \mathrm{~cm}$ and 0.262. $\mathrm{t}_{0}=-0.61$ year was obtained by the application of Pauly's empirical formula (Pauly \& Martosubroto, 1980). Santos (1963) estimated the Weight/length parameters as 2.98 and $0.013 \mathrm{~g} . \mathrm{cm}^{-2.98}$. Richardson \& Santos (1962) defined $\mathrm{L}_{50} \%$ as $19.20 \mathrm{~cm}$. $\mathrm{L}_{75 \%}$ $(=25.38 \mathrm{~cm})$ was calculated in the same way as for corvina using the $\mathrm{L}_{50 \%}$ and $\mathrm{L}_{75 \%}$ proposed by Vooren (1983) for pescada-foguete. Catchability (q) was estimated in the same way $(q=F / f)$ as for the other species, giving 0.00005 .

The total landings of these species in the State of São Paulo are composed of the registered landings of the pair trawlers; the landings of the pair trawlers that for some reason are not registered, the landings of otter trawlers which, although fishing for shrimps, also catch demersal fish, and the landings of other vessels that incidentally catch "pescadafoguete", "corvina" or "goete". These landings by other vessels represented, on average, $34.9 \%$ of the total landings of "corvina", $29.5 \%$ of the total landings of "pescada-foguete" and $30.8 \%$ of the total landings of "goete", during the period from 1982 to 1996.

It was necessary, for the simulations, to discover the effects of the fishing mortality resulting from the activity of the other vessels (unregistered landings of pair trawlers plus the landings of all other fisheries that incidentally catch these species). Thus, the controlled landings of the pair trawlers were subtracted from the total landings of each of the above species. The result was divided by the CPUE of the pair trawlers giving the effort of other vessels, in units of effort of pair trawlers.

(*) Coelho, J. A. P.; Castro, P. M. G. de; Bastos, C. M. L. F. \& Lima C. E. 1995. Estrutura em comprimento de Macrodon ancylodon, Cynoscion Jamaicensis e Balistes capriscus, desembarcados por parelhas sediadas em Santos/SP. In: ENCONTRO BRASILEIRO DE ICTIOLOGIA, II. Campinas, 1995. Resumo. Campinas, PUC-IGB. p. 12.
As the model is based on the numbers of individuals at each age, the study consisted of two stages. In the first the structure of the population for the year 1996, the basis for the simulations, had to be worked out. Since from 1976 to 1981 the variations in the fishing effort were small, the mean values of effort and catch for this period were taken, together with the catchability coefficients presented above, to calculate the numbers at each age, on the assumption of equilibrium, as described by Sparre \& Willmann (1993). Then, on the basis of these numbers, the structures of the populations for the following years up to 1996 inclusive, were estimated. In the second stage simulations for fleet sizes ranging from one to twenty pairs were made, keeping recruitment, fishing effort and catchability constant, from 1996 to 2012.

The initial numbers of the stocks for the period 1976-1981 were calculated using the equations proposed by Sparre \& Willmann (1993) under the equilibrium assumption. For this, it was considered that, under such conditions the numbers of individuals at each age in a given stock would remain constant and would be equal to those of single cohorts of the same ages. Thus, the formula: $\quad \mathbf{N}_{\text {age } t}=\mathbf{N}_{\text {age t-1 }} \cdot \mathrm{e}^{-\mathbf{Z}}$ was used, in accordance with the above mentioned authors. " $Z$ " for each age was given by $M$ (taken as equal for all ages) plus $F$ from the pair trawlers (being calculated as functions of the selectivity parameters, of the fishing effort and of the catchability coefficients, as indicated in Sparre \& Willmann (1993)) plus the $F$ of other vessels (similarly calculated by the program). For the calculation of $F$, the program takes into account the selectivity parameters $\mathrm{L}_{50 \%}$ and $\mathrm{L}_{75 \%}$, the mean length at each age, the catchability coefficient and the fishing effort, for each species. The number of individuals at each age multiplied by the corresponding $F$ gives the numbers of individuals caught at each age. These numbers are transformed into weight by the length/weight relationship. The sum of the catches over all the ages gives the total catch. The observed catches were divided by this calculated catch giving an index that multiplied the number of recruits. So the numbers of recruits were adjusted and the landings calculated for these three species were nearly equal to the mean landings observed in the period 1976-1981.

After this, these numbers for each year, from 1982 to 1996 inclusive, were calculated using Thompson \& Bell's (1934) model, with the equations proposed for BEAM4 (Sparre \& Willmann, 1993), the recruitment of previous years and the catchability coefficients of the current year being adjusted so that the landings calculated would be close to those observed. The fishing efforts observed in each year were used for this. Csirke \& Gumy (1996) have used a similar process for a bioeconomic analysis of the pelagic fisheries off Peru. One presumes that with this procedure the population 
structure, arrived at for 1996, came close enough to reality as to permit simulation of the effects of different fishing intensities for the following years. Then, taking the mean values of the catchability coefficients and numbers of recruits in the period 1982-1996, simulations were made using fishing efforts equivalent to the operation of one to tem pairs of trawlers for each year up to 2012. The yields calculated for 2011 , when the populations would reach a balance, were used to draw the curves of costs $x$ effort and profit $x$ effort. For these simulations the effort of the other vessels that catch these species (in units of effort of pair trawlers) was taken to be constant and equal to the observed mean of the previous ten years (1987-1996). Simulations were performed also with this effort reduced by $30 \%, 50 \%$ and $70 \%$.

For the definition of the fishing effort corresponding to a given number of pairs, the following schedule, taken as the ideal operation for each pair, was used as a basis for calculation:

$\begin{array}{lr}\text { Trips / pair / year } & 20 \\ \text { Fishing days / trip } & 12 \\ \text { Fishing days / pair / year } & 240 \\ \text { Days at sea / trip } & 15 \\ \text { Days at sea / pair / year } & 300 \\ \text { Days in port / pair / year } & 65 \\ \text { Hauls / trip } & 48 \\ \text { Length of each haul } & 3 \mathrm{hs} \\ \text { Hauls / pair / year } & 960\end{array}$

For the definition of the economic values to be fed into the model a questionnaire was prepared and sent to 35 fishing industries/boat owners in the States of Rio de Janeiro, São Paulo and Santa Catarina. From personal contacts we learned that only the fleet of pair trawlers based on São Paulo fished the southeastern stocks. Only five of the 35 questionnaires sent were answered. Of these five, four came from companies operating pair trawlers. These companies owned $80 \%$ of the pair trawlers still in operation; so the average values of these four answers (Table 1) were applied to the whole fleet.

Table 1. Basic economic values used to feed the model.

\begin{tabular}{|c|c|c|c|c|c|c|}
\hline Item & Firm A & Firm B & Firm C & Firm D & Mean & Sta. Deviation \\
\hline Sales price at landing-corvina $G-R S / k g$ & 1.20 & 1.10 & 1.50 & 0.73 & 1.13 & $\overline{0.32}$ \\
\hline Sales price at landing-corvina $\mathrm{M}-\mathrm{RS} / \mathrm{kg}$ & 0.70 & 0.90 & 1.10 & 0.60 & 0.83 & 0.22 \\
\hline Sales price at landing-corvina $S-R \$ / k g$ & 0.55 & 0.65 & 0.65 & 0.53 & 0.60 & 0.06 \\
\hline Sales price at landing-pesc. foguete $G-R \$ / \mathrm{kg}$ & 3.50 & 3.50 & 3.75 & 6.20 & 4.24 & 1.31 \\
\hline Sales price at landing-pesc. foguete $M-R \$ / k g$ & 2.60 & 2.50 & 3.00 & 4.20 & 3.08 & 0.78 \\
\hline Sales price at landing-pesc.foguete. $S-R \$ / \mathrm{kg}$ & 1.50 & 2.00 & 1.60 & 1.08 & 1.55 & 0.38 \\
\hline Sales price at landing-Goete $G-R \$ / k g$ & 1.25 & 1.75 & 1.25 & 1.31 & 1.39 & 0.24 \\
\hline Sales price at landing-Goete $M-R \$ / k g$ & 0.70 & 1.00 & 0.80 & 0.83 & 0.83 & 0.12 \\
\hline Sales price at landing-Goete $\mathrm{S}-\mathrm{R} \$ / \mathrm{kg}$ & - & - & - & 0.81 & 0.81 & - \\
\hline Sales price at landing-p.porco G - R\$/kg & 1.00 & 1.50 & 1.40 & 1.12 & 1.26 & 0.23 \\
\hline Sales price at landing-p.porco $S-R \$ / k g$ & - & 0.75 & - & - & 0.75 & - \\
\hline Hull depreciation $-\mathbf{R} \$$ /year & $8,000.00$ & - & . & . & $8,000.00$ & - \\
\hline Engine depreciation - RS/year & $10,000.00$ & - & - & - & $10,000.00$ & - \\
\hline Fishing gear depreciation - RS/year & 20.000 .00 & - & - & - & $20,000.00$ & - \\
\hline Interest on capital - $R \$ /$ year & $54,000.00$ & - & - & - & $54,000,00$ & - \\
\hline Insurance - R\$/year & 0.00 & - & 830,00 & - & 830.00 & - \\
\hline Overhead costs on salaries - RS/year & $12,000,00$ & - & $24,000.00$ & & $18,000.00$ & - \\
\hline License tax - R\$/year & 700.00 & - & - & - & 700.00 & - \\
\hline Other overhead costs - R\$/year & $35,000.00$ & - & - & - & $35,000.00$ & - \\
\hline Expenditure on fuel and lubricants per trip $-\mathbf{R} \$$ /trip & $8,000.00$ & $5,500.00$ & $4,000.00$ & - & $5,833.33$ & $2,020.73$ \\
\hline Expenditure on food per trip - R\$/trip & $1,500.00$ & $1,300.00$ & $1,000.00$ & - & $1,266.67$ & 25166 \\
\hline Expenditure on ice per trip - $R \$ /$ trip & $3,500.00$ & 4.500 .00 & $3,000.00$ & - & $3,666.67$ & 763.76 \\
\hline Costs of repairs and maintenance - RS/trip & $2,000.00$ & - & - & - & $2,000,00$ & - \\
\hline Costs of harbour and landing fees $-\mathrm{R} S /$ trip & $1,500.00$ & - & - & - & $1,500.00$ & - \\
\hline Fixed wages per trip - R\$/trip & $3,000.00$ & - & 600.00 & - & $1,800.00$ & - \\
\hline Other overhead costs per trip - RS/trip & $1,000.00$ & - & - & - & $1,000.00$ & - \\
\hline Crew's working days per year & 300 & 200 & 315 & 300 & 279 & 53 \\
\hline Land personnel's working days per year & 365 & 290 & 330 & 330 & 329 & 31 \\
\hline Investments in hull - R\$ & $200,000,00$ & - & $150,000.00$ & $500,000.00^{: 3}$ & $200,000.00$ & - \\
\hline Expected life of hull (years) & 25 & - & - & 12 & 25 & - \\
\hline Investments in engine - RS & $150,000,00$ & - & - & - & $150,000.00$ & - \\
\hline Expected life of engine (years) & 15 & - & - & - & 15 & - \\
\hline Investments in fisling equipment - R\$ & $100,000.00$ & - & - & - & $100,000.00$ & - \\
\hline Expected life of Equipment (years) & 5 & - & - & - & 5 & - \\
\hline Auctioning commission rate & $0 \%$ & $10 \%$ & $12 \%$ & $9 \%$ & $7.75 \%$ & $5.32 \%$ \\
\hline Rate of crew's share & $50 \%$ & $50 \%$ & $50 \%$ & $50 \%$ & $50.00 \%$ & $0.00 \%$ \\
\hline
\end{tabular}

"Investments in lull, engine and fishing equipment all included. 
It is important to bear in mind that depreciation (of boat, engine and fishing gear), although a very important datum for economic analysis, does not represent a value actually accounted by boat owners and is not, therefore, consciously taken into account by some of them. Further, many of the boats, including their engines and fishing gear, possibly the larger part of them, have already exceeded their normal life expectancy and thus are no longer accounted as depreciating. In spite of this, these values have been taken into consideration in the analysis.

Interest paid on capital is an item of cost that has been generalized, in absolute value, for the whole fleet, despite the fact that not all the boats carry the same charges, due to the lack of more precise information.

Fuel, lubricants, food, ice, repair, maintenance, etc. that vary both from boat to boat and by virtue of the number of trips made, were also generalized as a mean of the values given by the boat owners in order to permit an estimate of these costs for the various fishing efforts.

Costs of opportunity for the depreciation of hull, engine and fishing gear were considered zero because there are no economic studies available that allow us to make a precise assessment of these costs; besides that, the subject is too complex to be adequately covered within the scope of the present study.

Total costs over value of landings are represented by the sum of the crew's share and the auctioneer's commission. Once the catch is sold the boat owner deducts from the value of the landings, the costs of fuel and lubricants, food, ice, repairs and maintenance of the fishing gear and the landing taxes, the remainder being called the "shared rent". Fifty percent of it, called the "crew's share", is shared among the crew. In the model these are calculated as per effort unit to permit the simulation to be applied to a range of fishing efforts. The other component is the auctioneer's commission which is just a percentage of the total value of the landings and is paid by the boat owner alone.

\section{Results}

The economic figures found for the period .1976-1981, assuming the populations to be in equilibrium and using present values for the fish caught and for the costs of capture, were:

$\begin{array}{llr}\text { Value of landings } & \text { R\$ } & 7,143,841.16 \\ \text { Costs of capture } & \text { R\$ } & 12,108,848.12 \\ \text { Loss } & \text { R\$ } & -4,965,006.96\end{array}$

Although the value of the by-catch is not included, these numbers suggest that the pair trawling fleet had an overcapacity at that time. This conclusion is corroborated by the reduction the fleet underwent from that time until 1996.

Table 2 shows the performance of the pair trawling fleet based on Santos and fishing off southeastern Brazil, in 1996, presumed from the available data, wether including peixe-porco and other by-catch fish or not.

Table 2. Presumed performance of the pair trawler fleet based on Santos, SP, and fishing off SE Brazil, in 1996.

\begin{tabular}{|c|c|c|}
\hline & By-catch not included & By-catch included \\
\hline Fishing effort (hauls) & $514 \overline{8}$ & 5148 \\
\hline Number of trips & 126 & 126 \\
\hline Number of Pairs of trawlers & 11 (22 boats) & 11 ( 22 boats $)$ \\
\hline Corvina (small) & 368.49 & 368.49 \\
\hline Corvina (medium) & 326.47 & 326.47 \\
\hline Corvina (large) & 183.66 & 183.66 \\
\hline Pescada-foguete (laige) & 161.26 & 161.26 \\
\hline Goete (small) & 224.92 & 224.92 \\
\hline Goete (Inedium) & 110.41 & 110.41 \\
\hline Goete (large) & 156.84 & 156.84 \\
\hline \multicolumn{3}{|c|}{ Value of catch $(\mathrm{RS})(\mathrm{R} \$ 1.13=$ US\$ 1.00$)$} \\
\hline Corvina & $697,525.90$ & $697,525.90$ \\
\hline TOTAL & $2,083,075.62$ & $3,660,097.72$ \\
\hline \multicolumn{3}{|c|}{ Accounting (R\$) } \\
\hline Value of landings & $2,083,075.62$ & $3,660,097.72$ \\
\hline Value of landings/effort unit & 404.64 & 710.97 \\
\hline Shared rent/effort unit & 107.41 & 413.74 \\
\hline Crew share/effolt unit & 53.70 & 206.87 \\
\hline Auctioneer's commission/effort unit & 31.36 & 55.10 \\
\hline Costs depending on value of landings & $437,906.15$ & $1,348,636.42$ \\
\hline Total variable costs & $1,959,122.88$ & $1,959,122.88$ \\
\hline Total fixed costs & $1,611,830,00$ & $1,611,830,00$ \\
\hline Total costs of catch (RS) & $4,008,859.03$ & $4,919,589.30$ \\
\hline PROFIT (RS) & $-1,925,783.41$ & $-1,259,491.57$ \\
\hline
\end{tabular}


These results show that the costs turn out to be higher than the ex-vessel value of the landings, even when one adds the ex-vessel value of peixe-porco $( \pm 508 \mathrm{t}$ ) and other by-catch fish $( \pm 849$ t. $)$.

Simulations of the production and economic results for various fishing efforts until the population reached equilibrium, with the full effort of other vessels, as explained before, yielded the results shown in Figure 1.

This figure shows that the operation of this fleet, while restricted to southeastern stocks, results in economic losses if it comprises more than two pairs, exerting an effort of 1920 hauls per year distributed among 20 trips/pair. The value of the by-catch ("peixe-porco" and other fish) is not included. Estimates of the effects of the inclusion of these values, supposing they maintain the same ratio to the value of the target-species as in 1996, show profits for up to five pairs; however, Maximum Economic Yield (MEY) would be obtained with only one. Projections of these estimates show that Maximum Sustainable Yield (MSY) would be obtained with the operation of 17 pairs. Such a fleet would, however, have greater total and variable costs than the value of the landings; and so would not be economically viable.

If one reduced by $30 \%$ the fishing efforts applied to the three target-species by other fishing vessels, in relation to the mean of the last ten years, one could forecast profits for the operation of up to four pairs, taking only the main species into consideration (Fig. 2). Including "peixe-porco" and by-catch, up to six pairs would yield a profit. If that effort were reduced by $50 \%$, five pairs would have profits if by-catch were not included (Fig. 3) and up to 7 if it were. If the effort by other vessels were reduced by $70 \%$ those numbers would be six (Fig. 4) and eight, respectively. In the last three alternatives the $\mathrm{MEY}$ would be obtained with the operation of two or three pairs.

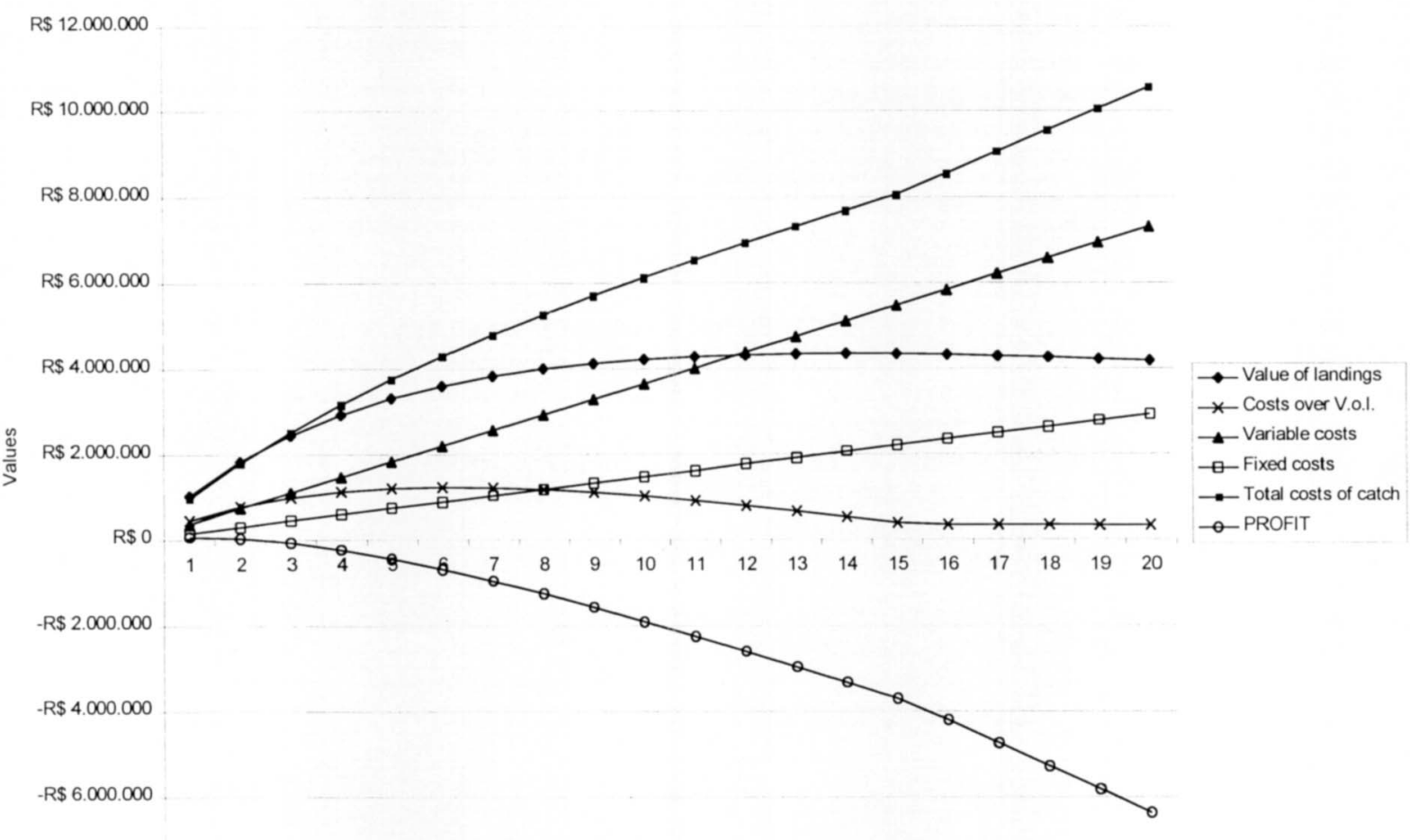

-R\$ 8.000 .000

Number of Pairs

Fig. 1. Costs of capture, ex-vessel value of landings and profit of the pair trawler fleet, at different levels of fishing effort, once equilibrium is attained. 
R\$ 12.000 .000

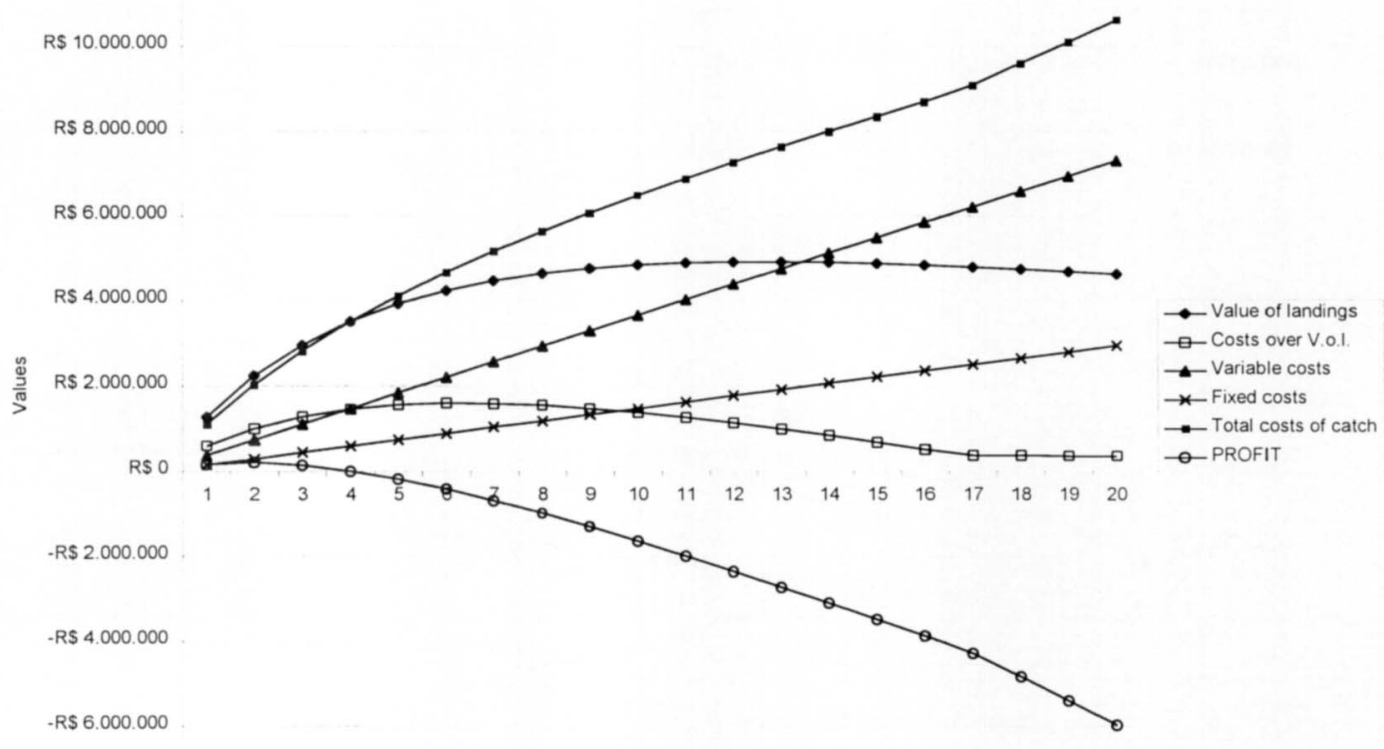

-RS 8.000 .000

Number of pairs

Fig. 2. Costs of capture, ex-vessel value of landings and profit for the pair trawlers fleet, at different levels of fishing effort, once equilibrium is attained, with effort from other vessels reduced by $30 \%$.

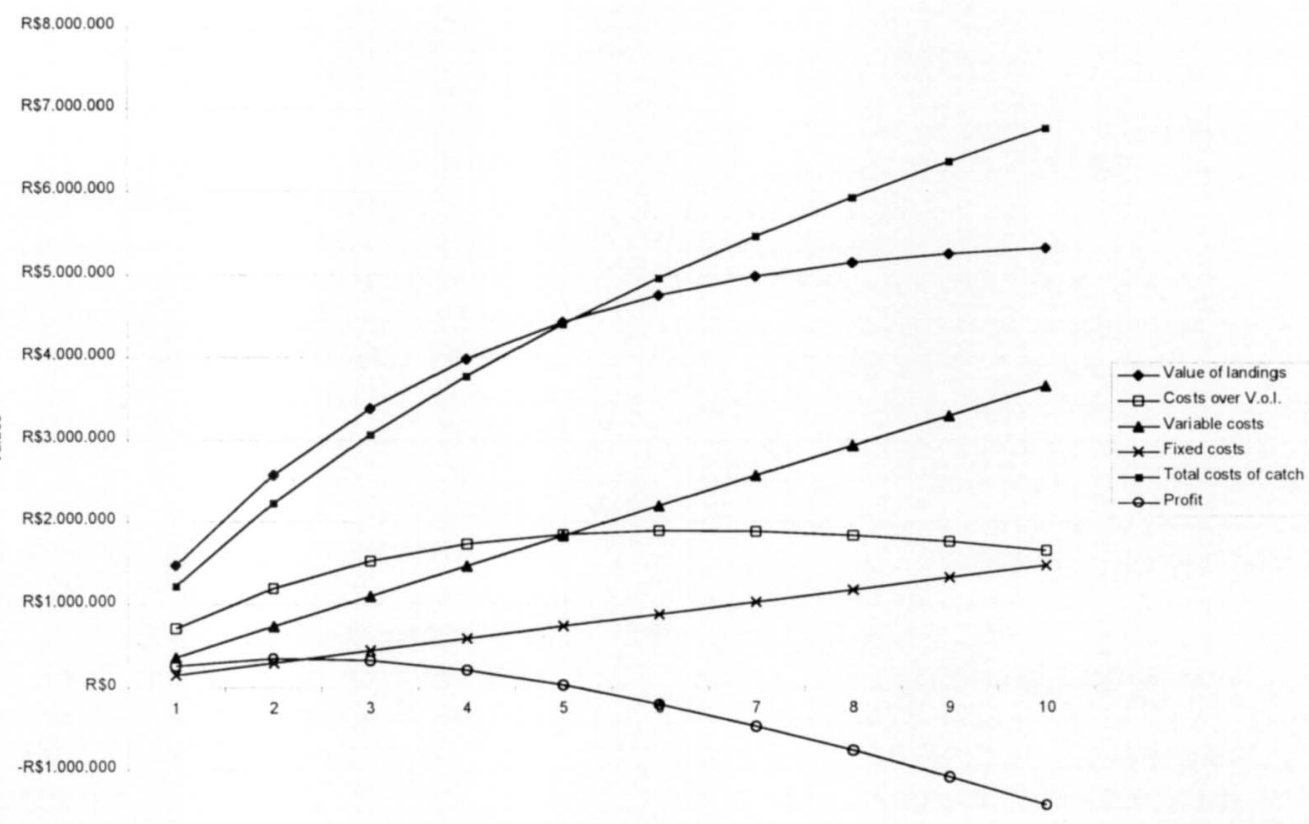

$-R \$ 2.000 .000$

Number of Pairs

Fig. 3. Costs of capture, ex-vessel value of landings and profit for the pair trawlers fleet, at different levels of fishing effort, once equilibrium is attained, with effort from other vessels reduced by $50 \%$. 


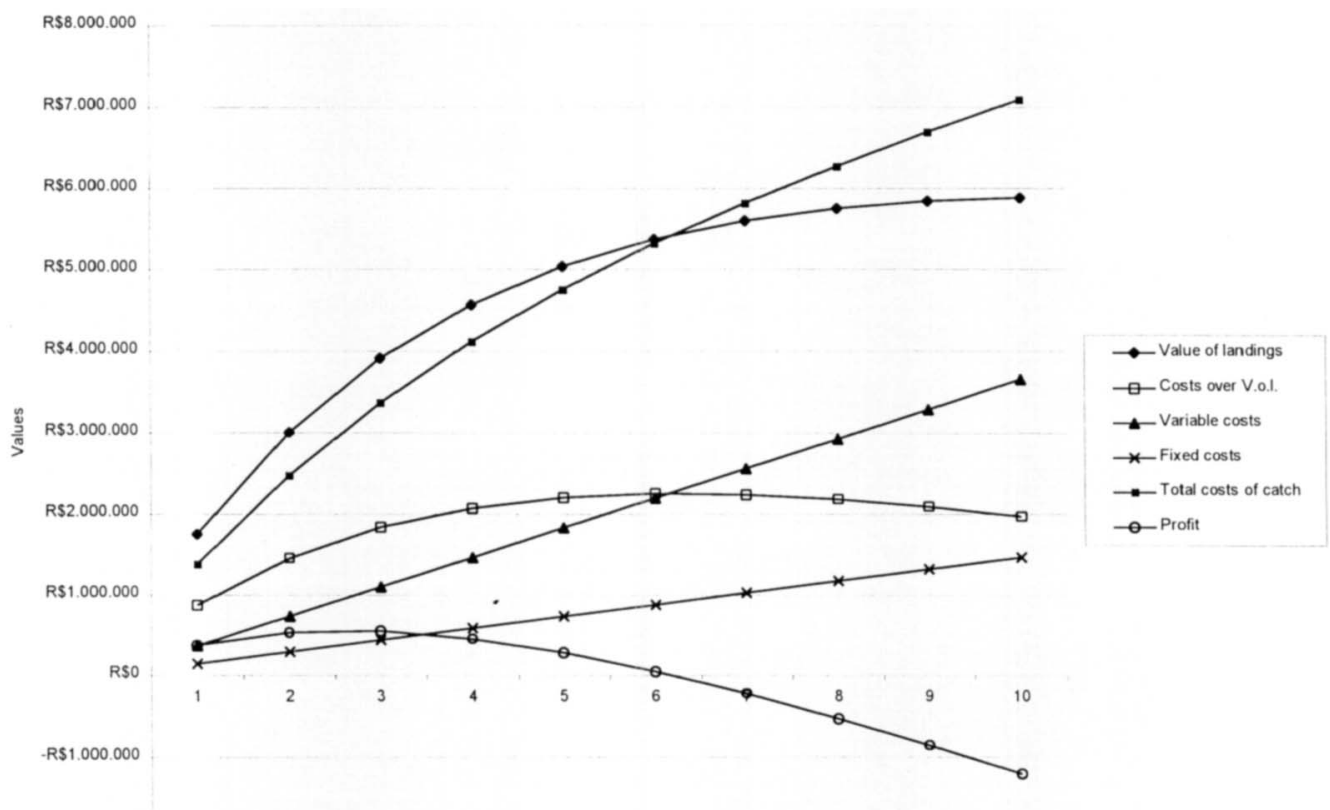

-R\$2.000.000

Number of pairs

Fig. 4. Costs of capture, ex-vessel value of landings and profit for the pair trawlers fleet, at different levels of fishing effort, once equilibrium is attained, with effort from other vessels reduced by $70 \%$.

\section{Discussion}

The fishing effort exerted by other vessels in catching the species studied cannot be evaluated as a function of the effort of the pair trawlers; neither can one correlate it with the total effort of the other fleets since these species are caught only incidentally. The forecasts of the performance of the pair trawler fleet are affected by this problem. Repetitions of the simulations using different constant levels of fishing effort by other vessels permitted the definition of scenarios in which the operation of the pair trawlers, that initially does not seem viable, can produce profits of the order of $\mathrm{R} \$ 545.000,00$. The proposed reduction of the effort (fishing mortality) by other vessels might be attained, among other means, by the use of Fish Excluding Devices (FEDs) by the shrimp trawlers.

The generalization of the costs of insurance represents an overestimation, since most of the boats are not insured. Actually most of the boat owners do not insure their boats because of the financial problems arising from their low returns and the high cost of this kind of insurance.

Harbour and landing fees are other costs that may be overestimated by their generalization, since some boats dock in their own private ports and pay no taxes. However, those accrued costs (such as labour for the unloading of the catch and repairs and maintenance of the docks) that are not apparently covered by other items, what means that the generalization might lead to a lesser error than its omission.

When the presumed performances of the fleet for 1976-81 and for 1996 are compared it is to be seen that the reduction of $61 \%$ in the number of boats (from 1981 to 1996) yielded a reduction of $71 \%$ in the ex-vessel value of the landings of the target species that was partially offset by the reduction of $67 \%$ in the total catch costs. These changes resulted in a $61 \%$ reduction in the losses; but, even so, the negative results persist.

On analyzing the above results we may detect two causes for the poor performance of this fishery. One is overcapitalization (a large number of boats operating well below their full capacity) which represents higher fixed costs. The second is the catch of the target species of the pair trawler fishery by other fisheries, which leads to growth overfishing, meaning that many individuals are caught before attaining the size at which they would have the highest market value.

Both these factors are present in the presumed performance for 1996; however, the available data are insufficient to enable us to work out what proportion (of the loss) stems from each of them. In the simulations for Maximum Economical Yield the overcapitalization has been removed, in the 
sense that all boats were taken as operating at their full capacity. The effect of growth overfishing can, thus, be appraised from the scenarios presented in which the catch by other vessels has been diminished.

Some points may, however, enable one to understand why, even though this study shows such an unfavorable situation, the pair trawler fleet based on São Paulo should still operate about the same number of boats:

a) This study was performed on the basis of the belief that the fleet fishes only the southeastern stocks, which is not completely true. Many of the boats also fish the stocks to the north and south of the area studied. Occasionally, due to market questions, fish caught in these regions are landed and sold in the nearest ports. In this way this fish and their value do not appear in São Paulo's landing statistics;

b) Part of the fish caught outside the study area are commercialized in São Paulo. However this production, although included in the statistics, has not been taken into consideration, because it does not originate in the populations studied and so has not contributed to the value of the landings. Similar treatment was given to the corresponding fishing effort, which was not taken into account for cost composition.

c) The majority of the boat owners that operate pair-trawlers do also operate other fishing vessels. So their financial results arise from a composition of the results of each vessel, so that some which do well compensate for others which do badly.

d) As commented above, about $63 \%$ of the fixed costs (insurance, depreciation, opportunity costs, etc..) do not represent the boat owners' real expenditure.

The results obtained show that, if the catch of the species under consideration by other vessels were not to be reduced, the operation of the pair trawlers related only to the southeastern stocks would be economically impracticable. However, it is impossible to foresee the volume of these species that will be caught by other vessels since these capture them just incidentally while fishing the species of their own particular interest. Further, the attribution of the same catchability coefficient and same selectivity parameters to both the pair trawlers and the other vessels (implicit in the way the effort for other vessels has been calculated) represents an erroneous estimate of the age composition of the catch of those other vessels.

Finally, one must bear in mind that the results of the simulations for Maximum Economic Yield and for Maximum Sustainable Yield are based on the assumptions of constant recruitment, constant catchability coefficient, constant fishing effort and constant natural mortality. So the results obtained should not be taken as forecasts of the absolute values to be found in each of the scenarios analyzed but rather as indicators of the tendencies of the stocks studied and of the catches they could yield as well as of the costs and rents to be expected in relation to demersal fisheries off southeastern Brazil.

One must add to this the fact that the values simulated by this study are "mean" values for the fleet. This means that some of the boat owners may be accounting real gains, and have no reason to abandon this activity, while those who had losses this year expect to have a real gain next year and they thus remain in the fishing industry. Hilborn \& Walters (1992) point out, also, that those who leave the fisheries tend to be substituted by others who expect to do better than they. Besides that, as the alternative fisheries in which these boats could be deployed are already overexploited, and there is no market for these old boats, it is most probable that boat owners will try to expand their fisheries to other fishing grounds and other species; while at the same time they will probably put pressure on the government asking for subsidies to reduce fishing costs. However, unless there is a rigorous limitation on the number of boats operating in this fishery, the subsidies, if conceded, would stimulate an increase in the number of boats such as to make the business unprofitable again.

\section{Acknowledgements}

The authors wish to thank the "Instituto de Pesca" of the "Secretaria de Agricultura e Abastecimento" of the State of São Paulo, as also the "Instituto Oceanográfico" of the "Universidade de São Paulo" and the "Instituto de Biociências" of the "Universidade Estadual Paulista" which provided the facilities for them to undertake this project. Thanks are also due to FAPESP - Fundação de Amparo à Pesquisa no Estado de São Paulo - which granted the funds necessary for their research. We must also express our gratitude to Dr. Victoria Isaac for her fruitful comments on the use and values of $t_{0}$, and Mrs. Marcia M. Tinen and Claudia M. D. Mucinhato for their help in the compiling of the data used.

\section{References}

BRASIL-SUDEPE. Superintendência de Desenvolvimento da Pesca. 1969. Decreto-Lei $n^{\circ} 221$, de 28.02.67. Dispõe sobre a proteção e estímulos à pesca. Coletânea dos atos regulamentadores, emanados das leis básicas da SUDEPE.

Castro L. A. B. de 1998. Aplicação do modelo BEAM4 à pesca de parelhas no sudeste do Brasil $\left(23^{\circ} \mathrm{S}\right.$ a $\left.29^{\circ} \mathrm{S}\right)$. PhD. thesis. Universidade de São Paulo, Instituto Oceanográfico. 149p. 
Castro L. A. B. de \& Castro P. M. G. de 1995. Variação do comprimento médio da pescadafoguete (Macrodon ancylodon) capturada na região sudeste do Brasil $\left(23^{\circ} \mathrm{S}-29^{\circ} \mathrm{S}\right)$ e desembarcada em Santos, SP, no período 19761990. Publção esp. Inst. oceanogr., S Paulo, (11):187-196.

Csirke, J.; Gumy, A. A. $1996 . \quad$ Análisis bioeconómico de la pesqueria pelágica peruana dedicada a la producción de harina y aceite de pescado. Bol. Inst. Mar, Peru, 15(2):25-68.

Gordon, S. H. 1954. Economic theory of a common-property resource: the fishery. J. polit. Econ., 62:124-142.

Hardin, G. 1968. The tragedy of commons. Science, 162(3859): 1243-1248.

Hilborn, R. \& Walters C. J. 1992. Quantitative fisheries stock assessment: choice, dynamics and uncertainty. New York, Chapman \& Hall. 570p.

Isaac-Nahun, V. J. 1989. Analysis of methods for the estimation of fish growth parameters, based on data from family sciaenidae and on simulated data. PhD Thesis. Kiel, Christian-AlbrechtsUniversität. 244p.

Isaac-Nahun, V. J. \& Vazzoler, A. E. A. de M. 1983. Biologia reprodutiva de Micropogonias furnieri (Desmarest, 1823) (Teleostei, Sciaenidae). 1. Fator de condição como indicador do período de desova. Bolm Inst oceanogr., S Paulo, 32(1):6369.

McKelvey, R. 1989. Common Property and the conservation of natural resources. In: Levin, S. A.; Hallam, T. G. \& Gross, L. J. eds. Applied mathematical ecology. New York, SpringerVerlag. p. 58-80.

Pauly, D. 1980. On the interrelationship between natural mortality, growth parameters and mean environmental temperature in 175 fish stocks. J. Cons. int. Explor. Mer, 39(2):175192.

Pauly, D. \& Martosubroto, P. 1980. The population dynamics of Nemipterus marginatus (Cuvier \& Val.) off Western Kalimantan, South China Sea. J. Fish. Biol., 17(3):243-253.

PDP/SUDEPE. Programa de Desenvolvimento Pesqueiro. 1981. Relatório do Grupo de Trabalho e Treinamento (GTT) sobre peixes demersais. Tamandaré 29/06-29/07. (mimeo).
Randall, A. 1987. Resource economics: an economic approach to natual resource and environmental policy. New York, John Wiley \& Sons. $434 \mathrm{p}$.

Richardson, I. D. \& Santos, E. P. 1962. Note on the selectivity of meshes used by the Santos fishing fleet. Bolm Inst. oceanogr., S Paulo, $12(1): 33-52$.

Ricker, W. E. 1958. Handbook of computations for biological statistics of fish populations. Bull. Fish. Res. Bd. Can., 119:1-300.

Santos, E. P. 1963. Growth of Goête: quantitative aspects. Bolm Inst. oceanogr., S Paulo, I3(1):185-190.

Santos, E. P. 1968. Estudo populacional do Goête, Cynoscion petranus (Ribeiro, 1915). Bolm Inst. oceanogr., S Paulo, 17(1):17-31.

Sparre P. \& Willmann R. 1993. Software for bioeconomic analysis of fisheries: BEAM IV: Analytical bio-economic simulation of spacestructured multi-species and multifleet fisheries. FAO Computerized Information Series (Fisheries), $\mathrm{n}^{\circ}$ 3. $2 \mathrm{v}$. (and microcomputer software).

Thompson, W. F. \& Bell, F. H. 1934. Biological statistics of the Pacific halibut fishery. 2. Effect of changes in intensity upon total yield and yield per unit of gear. Rep. int. North Pacific Fish. Comm., 8:1-149.

Valentini, H.; Castro, P. M. G. de; Servo, G. J. de M. \& Castro, L. A. B. de 1991. Evolução da pesca das principais espécies demersais da costa sudeste do Brasil, pela frota de arrasteiros de parelha baseada em São Paulo, de 1968 a 1987 . Atlântica, Rio Grande, 13 (1):87-95.

Vazzoler, A. E. A. de M. 1971. Diversificação fisiológica e morfológica de Micropogon furnieri (Desmarest, 1823) ao sul de Cabo Frio, Brasil. Bolm Inst. oceanogr., S Paulo, 20(2):1-70.

Vooren, C. M. 1983. Seleção pela malha na pesca de arrasto da castanha Umbrina canosai, pescada Cynoscion striatus e pescadinha Macrodon ancylodon no Rio Grande do Sul. Doc. Téc. Oceanogr., Rio Grande. 4:32p.

Yamaguti, N. 1967. Desova da pescada-foguete, Macrodon ancylodon. Bolm Inst. oceanogr., S Paulo, 16(1):101-106.

(Manuscript received 04 September 2000: revised 17 December 2001; accepted 08 March 2002) 